On Task 



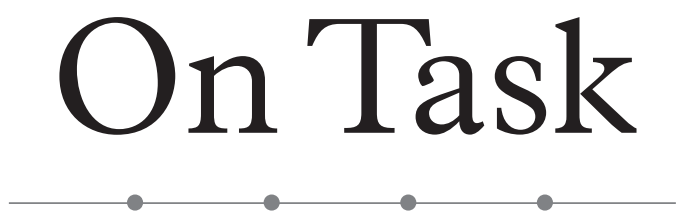

How Our Brain Gets Things Done

\section{David Badre}

With a new preface by the author 
Copyright (C) 2020 by Princeton University Press

Preface to the paperback copyright (C) 2022 by Princeton University Press

Requests for permission to reproduce material from this work should be sent to permissions@press.princeton.edu

Published by Princeton University Press

41 William Street, Princeton, New Jersey 08540

6 Oxford Street, Woodstock, Oxfordshire OX20 1TR

press.princeton.edu

All Rights Reserved

LCCN: 2021948917

First paperback edition, 2022

Paper ISBN 9780691234700

Cloth ISBN 9780691175553

ISBN 9780691240145 (ebook)

British Library Cataloging-in-Publication Data is available

Editorial: Hallie Stebbins and Kristen Hop

Production Editorial: Ali Parrington

Jacket/Cover Design: Layla Mac Rory

Production: Jacqueline Poirier

Publicity: Sara Henning-Stout and Katie Lewis

Copyeditor: Barbara Liguori

This book has been composed in Arno

Printed in the United States of America 
To my family. 
